\title{
Stamcelleforskning - nytt håp?
}

Det fertiliserte egg representerer den totipotente stamcelle. Fra denne ene cellen utvikles alle kroppens celler og vev samt mesteparten av morkaken og hinnene som omgir fosteret. Blant de første cellene som eggcellen gir opphav til, er de embryonale stamceller, som er på plass allerede fem dager etter befruktningen. Mens fosteret vokser i størrelse gjennom celledeling skjer det også en spesialisering av cellene, idet organer bestående av spesifikke celletyper dannes. Organogenesen skjer ved hjelp av vevsspesifikke stamceller som gir opphav til de celletyper som finnes i organet. Gjennom resten av livet er disse stamcellene viktig for vedlikehold, spesielt i vev med rask celleomsetning (f.eks. hud eller tarm), og i mange vev også for regenerasjon etter skade.

De senere års forskning har vist at man fra embryonale stamceller kan generere alle de spesialiserte celletyper en organisme består av. Dette har gitt et sterkt og begrunnet håp om at man ved hjelp av slike celler i fremtiden skal kunne behandle en rekke ulike sykdommer, eksempelvis Parkinsons sykdom eller diabetes. Bruk av humane embryoer begrenses imidlertid av etiske betenkeligheter, og kliniske transplantasjoner hemmes av vevsuforlikelighet. Ideelt sett skulle man derfor, både med tanke på forskning og fremtidige transplantasjoner, ønske seg en ubegrenset mengde av autologe celler med den embryonale stamcellens egenskaper.

Veien fra den totipotente celle til en ferdig differensiert lever-, muskel- eller nervecelle er blitt sett på som en enveiskjørt gate. Man mente at en ferdig differensiert og spesialisert celle ikke kunne gjenvinne evnen til å være opphav til flere ulike celle- og vevstyper.

Briten sir John B. Gurdon (f. 1933) var av dem som tidlig satte spørsmålstegn ved om den differensieringen som skjer når en celle modnes og spesialiseres, skyldes irreversible restriksjoner i det genetiske materialet i kjernen. Gurdon disputerte ved Oxford i 1960. Han var postdoktor ved California Institute of Technology og ble senere professor i cellebiologi i Cambridge.

Han hentet cellekjerner fra ferdig differensierte epitelceller i tarmen hos rumpetroll og transplanterte disse til froskeegg. I den første serien transplanterte han cellekjerner til 726 egg. De fleste forsøkene resulterte riktignok i ulike grader av abnormalitet - fra egg som ikke delte seg til individer med misdannelser, men i ti tilfeller oppnådde han at transplanterte egg utviklet seg til normale rumpetroll (1). Senere samme år viste han at han kunne produsere normale voksne frosker på samme måte.

Disse resultatene ble først betraktet med skepsis, men ble senere reprodusert av andre forskere og la grunnlaget for den senere kloning av pattedyr som startet med sauen Dolly i 1997 (2). Slik viste man at også hos pattedyr kan somatiske celler reprogrammeres.

Av disse forsøkene fulgte det logisk at det må finnes virkestoffer i oocytter som kan omdanne ferdig differensierte celler til totipotente stamceller. Med japaneren Shinya Yamanaka (f. 1962, samme år som Gurdon publiserte sine resultater) gjorde feltet et nytt kvantesprang fremover da han viste at man kan reversere differensierte celler til såkalte induserte pluripotente celler (iPS) uten å gå veien om kjernetransplantasjon. Yamanaka er professor ved universitetet i Kyoto. Han studerte medisin i Kobe og spesialiserte seg i ortopedisk kirurgi før han bestemte seg for å konsentrere seg om basalforskning.
Yamanaka interesserte seg for gener som bidrar til at embryonale stamceller holdes i stamcellestatus (i motsetning til å differensieres). Sammen med Kazutoshi Takahashi undersøkte han systematisk effekten av 24 slike gener og fant ut at overuttrykking av en kombinasjon av fire av disse (Oct3/4, Sox 2, c-Myc og Klf4) kan transformere en differensiert celle til en iPS-celle (3).

I Norge deltar vi tett i denne utviklingen, og flere forskergrupper arbeider med stamceller med tanke på nye behandlingsformer innen blant annet ortopedi, øyesykdommer, diabetes, sårbehandling og nevrodegenerative sykdommer. På noen områder er det alt etablert behandling. Intravenøs injeksjon av vevsforlikelige stamceller fra en frisk givers beinmarg kan gi komplett erstatning av syke stamceller i beinmargen ved leukemi. Oslo universitetssykehus har egne laboratorier hvor det dyrkes stamceller som brukes i klinisk praksis. Det er oppnådd gode resultater ved eksempelvis transplantasjon av stamceller fra beinmarg til ledd med bruskskade og fra langerhansøyer ved type 1-diabetes. Studier hvor man bruker stamceller til å reparere skader i øyets hornhinne og studier der stamceller fra fettvev utprøves i behandling av pasienter med kroniske sår og fistler etter strålebehandling er startet.

Normalt differensierer vevsegne stamceller kun til de celletyper som finnes i samme vev. Det ser imidlertid ut til at stamceller fra fettvev kan brukes i behandling av diabetes. Vi har også eksperimentell kunnskap om at stamceller fra for eksempel neseslimhinne og beinmarg kan differensieres til celler med nevronale egenskaper og at stamceller fra menneskehjerne kan utvikles til blant annet hjertemuskelceller i kylllingfostre. Dette kan åpne for celleterapi på tvers av vevsgrenser uten genmodifisering.

Stamcelleteknologien vil imidlertid ikke være begrenset til produksjon av én enkelt spesialisert celletyper. Nylig transplanterte en gruppe ved Karolinska Sjukhuset i Stockholm et nytt luftrør, produsert ved hjelp av stamceller og en bioartifisiell forskaling, til en pasient med trakealkreft (4). Denne teknologien er nå under etablering hos oss.

Årets nobelpris i fysiologi eller medisin og den utvikling vi ser innen stamcelleteknologien og regenerativ medisin åpner nye, spennende fagområder og gir håp om nye terapiformer for våre pasienter.

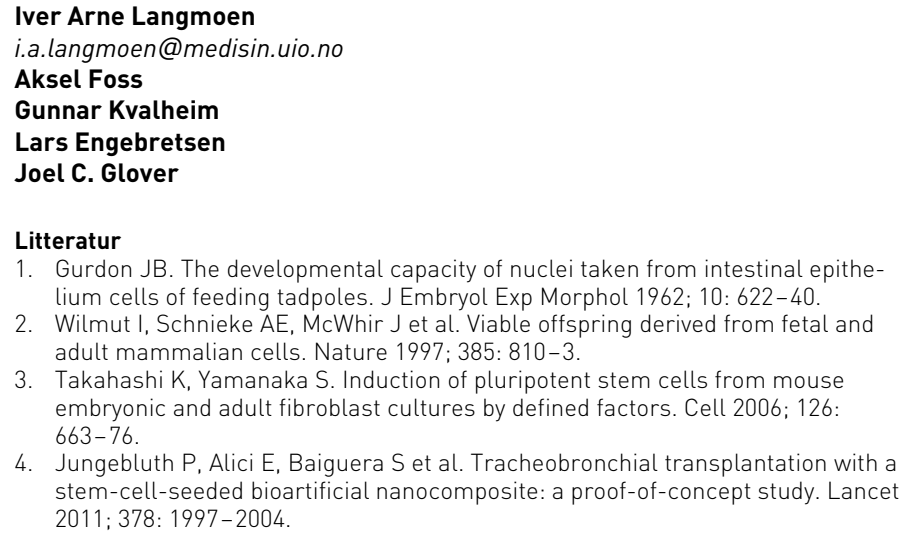

4. Jungebluth P, Alici E, Baiguera S et al. Tracheobronchial transplantation with a stem-cell-seeded bioartificial nanocomposite: a proof-of-concept study. Lancet 2011; 378: 1997-2004.

Forfatternes minibiografier finnes kun i Tidsskriftets nettutgave 